\title{
COMMUNITY PARTICIPATION IN WASTE MANAGEMENT IN CHANGWON CITY, SOUTH KOREA
}

\author{
Rita Rijayanti ${ }^{1, *}$, Truong Thi Thuy ${ }^{2}$, Qi Ou ${ }^{3}$ \\ 1) Department of Eco-friendly Offshore Plant FEED Engineering, Changwon National University, \\ Changwon, Republic of Korea \\ 2) Department of Chemistry, Changwon National University, Changwon, Republic of Korea \\ ${ }^{3)}$ College of Materials and Chemistry \& Chemical Engineering, Chengdu University of Technology, \\ China Department of Software Engineering, Universitas Pendidikan Indonesia, Indonesia
}

\begin{abstract}
Changwon City, located in the southern central region of Gyeongsangnam-do in South Korea, has become a major center of industrial economy in the central region of Gyeongnam. To achieve good waste management can be done by handling: institutional aspects, financial aspects, regulatory aspects (legal), aspects of community participation, and operational technical aspects. The purposes of this research are to find out the participation of the community in Changwon City, South Korea and to investigate the type of management carried out in Changwon City, South Korea. The literature study method uses secondary data from Changwon City, South Korea and several studies on waste management to support and supplement information from the interviews. Government of South Korea adopted the concept of a volume-based waste fee system and collecting the recyclable waste, which is a volume-based waste disposal system, where each citizen has to pay for every plastic waste that will be used. The greater the waste production will need the greater the costs. Communities are required to sort out their waste before putting it in a plastic bag according to the type of waste, especially waste that can still be recycled. Korea has also established an expanded producer responsibility system and recycles its construction waste. Korea's waste information system has resulted in cost savings, promoted transparency, and eliminated illegal waste disposal. The effects of this policy include reducing the production of solid household waste, contributing to the completion of separate disposal, collecting waste and recyclable goods securing the cost of waste treatment from the benefits of the VBWF system and economic utilization.
\end{abstract}

Keywords: community participation, government policy, waste handling

\section{Introduction}

South Korea is one of the countries in East Asia that is considered successful in managing waste and even transforming it into a resource that absorbs thousands of workers. The State of

${ }^{*}$ Corresponding Author:

E-mail: rita.rijayanti@unpas.ac.id

Received: 24 February 2020

Revised: 1 March 2020

Accepted: 17 March 2020
Ginseng continues to develop research in the context of developing a green industry for the implementation of environmentally sound development. Around 1977, waste management in South Korea was still not well managed. Garbage and sewage pollution, both domestic and industrial waste, pollutes the ground water and the Han River, the river that divides Seoul City. At that time waste processing in South Korea was centered at the Nanji landfill site. The 
Nanji landfill is still operated with an open dumping system, which is open disposal without any processing. The operation of the Nanji TPA has many technical, environmental and social problems. Technically, the obstacles faced are lack of experience and limited human resources in handling waste, not yet mastered waste to energy techniques. Many environmental pollution and disease outbreaks occur in the community due to leachate, insects, odors, and methane gas (Hendra, 2016).

Changwon City, located in the southern central region of Gyeongsangnam-do in South Korea, has become a major center of industrial economy in the central region of Gyeongnam. Located in the southeastern part of Korea along with Busan, Changwon is bordered by Masan Bay and Jinhae Bay in the south, Haman and Miryang in the north, Busan and Gimhae in the east, and Goseong in the west. Changwon City also carries out waste management well.

To achieve good environmental management, the South Korean government made a policy on handling the environment recorded at ECOREA 2015 - volume 3 related to environment and waste issues, with a focus on protecting public health from environmental risks and controlling chemical contamination from recycled waste.

To achieve good waste management can be done by handling: institutional aspects, financial aspects, regulatory aspects (legal), aspects of community participation, and operational technical aspects. These five aspects are interrelated and must be considered to create an effective waste management system. Without the participation of waste-producing communities, all planned waste management programs will not run properly (ECOREA,
2015), (Lee, 2005), (https://global-recycling. info/archives/3205, accessed February 2020).

The purposes of this research are to find out the participation of the community in Changwon City, South Korea and to investigate the type of management carried out in Changwon City, South Korea.

\section{Research Methodology}

According to Sugiyono (2018) the data collection method is the most strategic step in research, because the main objective of the research is to obtain data. In this research the method used is the interview method and literature study. The interview method is carried out to the public and experts who are waste managers in Changwon City, South Korea. The literature study method uses secondary data from Changwon City, South Korea and several studies on waste management to support and supplement information from the interviews.

\section{Result and Discussion}

Government Policy

The South Korea Government has determined policy to several aspects considering environmental health and waste management.

1. Environmental Health

Main Policy Framework

1) Protecting Public Health from Environmental Risks

2) Chemical Control Systems

3) Survey of Chemical Emissions and Emission Reductions

4) Improve the Environment

Current Policy Focus

1) Strengthened Chemical Safety Management 
2) Chemicals which can be controlled internationally

3) Asbestos Safety Management and Asbestos Injury Assistance

Key Facts and Trends

1) Number of Environmental Disease Patients

2) Chemical Distribution and Emissions

2. Waste

Main Policy Framework

1) Direction of Resource Circulation Policy

2) Waste Management and Reduction

3) Waste Recycling

4) Hazardous Waste Management

Current Policy Focus

1) Excessive Products and Excessive Packaging Products

2) Volume-based Food Waste Cost System

3) Targets for Recycling of Electrical \& Electronic Product Waste

Management system

4) Free collection of large-scale household waste products

5) Waste to Energy

Main facts and trends

1) Generating Waste

2) Waste Management

In the field of waste management, the South Korean Government provides support in the form of preparing legislation and its implementation. Since 1986, a Waste Management Act has been made which includes waste classification, the division of responsibilities of each stakeholder, and waste management techniques, including recycling techniques. In 1990, the Government of South Korea adopted the concept of a volume-based waste fee system and collecting the recyclable waste, which is a volume-based waste disposal system, where each citizen has to pay for every plastic waste that will be used. The greater the waste production, the greater the costs. The rubbish produced is collected in garbage bags that must be purchased by the community.

\section{Waste Management}

Based on Hendra (2016), South Korea carries out management by:

\section{Waste Management at the Source}

The South Korean government has implemented a policy for sorting waste at source with the following classification:

a. Organic trash

b. Inorganic waste

c. Other waste that is not included in this category, for example: eggshells, disposable diapers, and others.

Communities are required to sort out their waste before putting it in a plastic bag according to the type of waste, especially waste that can still be recycled. The community is also encouraged to carry out the process of recycling waste, for example by returning used bottles of drinks purchased, and then the community will get a deposit from the purchase price of these drinks. If this regulation is not obeyed, it will be subject to very large sanctions / fines, and even garbage will not be transported. The sanction is not only given personally (individually), but also applies to the surrounding community, so that they will supervise and remind each other.

Community involvement and concern in waste management is very large. They create communities that help in supervising waste management in their respective environments. In 
addition, all information related to activities in the landfill site is published to the public through the internet, so that the community can monitor the implementation of activities in the landfill site, such as waste data entering the landfill site, parameters of leachate treatment results, etc. From the waste manager, the surrounding community gets compensation of approximately $10 \%$ of the total cost of handling waste distributed in the form of providing educational facilities, sports, and so on.

Information Management for Reducing Waste in Korea

Korea produced 18.2 million tons of municipal waste in 2014 and recycled 58 percent of its waste, reaching one of the highest levels of the Organization for Economic Cooperation and Development Countries (Kho and Lee 2016). According to the World Bank in What a Waste 2.0 (2018) Korea is also a global leader in a progressive waste management law, where residents are encouraged to take part in waste management activities such as recycling plastics through the deposit of a refund system, reducing waste through fee-based volume, and separate different waste streams at the household and business level. Korea has also established an expanded producer responsibility system and recycles its construction waste. Korea established a waste management information system in 2001. This system digitally records statistics from waste generation to transportation and final disposal.

In 2013 , a 20 percent reduction in food waste was achieved in the capital city of Seoul through this digital volume-based system. Finally, Information Systems are used in recycling by matching suppliers and buyers of recycled materials on a centralized platform. This platform provides information about recycling prices and technology, matches businesses with recycling companies, and facilitates bidding electronically. As of September 2013, a total of 69,000 members had registered on the platform.

Korea's waste information system has resulted in cost savings, promoted transparency, and eliminated illegal waste disposal. The gradual implementation of the system allows stakeholders to adjust to the system. Other success factors include public relations strategies that increase awareness and strong feedback mechanisms that allow the system to improve over time. Most importantly, the waste information system allows volume-based waste costs to be implemented, which has led to valuable changes in citizens' behavior and reduced resource consumption.

\section{Volume-Based Waste Fee System}

The volume-based waste payment system is a policy to charge costs proportionally to the amount of waste disposed of. In Seoul, all waste must be disposed of in accordance with the VBWF system, with the exception of items that can be recycled, large waste and coal briquettes which have different handling and predetermined costs and are charged in proportion to the amount disposed of. Depending on the type of waste, the volume is measured differently. Waste is divided into general waste (MSW) to be burned or buried, food scraps, and recyclable waste that can be converted into resources.

Public rubbish is rubbish that will be burned or buried. The volume of waste is measured through standard garbage bags, which are carried by the district, or office to be divided 
into household, commercial, and business use. Bags of 2, 3, 5, 10, 20, 30, 50, 75, and 100 liter sizes, with people able to buy the size and number of bags they want at the designated store. Therefore, general waste is processed based on volume based filling systems.

Since 2013, food waste has been subject to a volume-based waste fee system in Seoul. The chip or sticker system requires removal to purchase a payment chip or sticker and attach it to a standard collection container for collection. The container functions as a disposable volume measuring device or a monthly volume measuring device. The advantage of an RFID system is that it accurately measures the volume of waste and costs charged according to the total volume. However, RFID systems can be very complicated because they must be equipped with a weight measuring device, a recognition recognition system, and volume tracking \& storage devices. The effects of this policy include reducing the production of solid household waste, contributing to the completion of separate disposal, collecting waste and recyclable goods securing the cost of waste treatment from the benefits of the VBWF system and economic utilization.

\section{Community Participation in Changwon City}

Waste management in Changwon City follows the existing management system in Korea. One of them is scheduled garbage disposal. Disposal of waste is carried out in accordance with a predetermined schedule for garbage collection and collection. Disposal time: 20:00 - 00:00 on the day before collection. The public is advised not to dispose of garbage during the day. Landfill sites for household waste are divided based on dwellings such as apartment buildings: in designated places in the compound and single houses: In front of a person's gate or designated collection site. Trash that has been disposed of previously must be disaggregated according to the provisions in Changwon City. How to dispose of household waste can be seen in Table 1.

Table 1. How to dispose of household waste

\begin{tabular}{|c|c|c|}
\hline $\begin{array}{l}\text { Waste } \\
\text { Type }\end{array}$ & $\begin{array}{c}\text { Waste } \\
\text { Disposal } \\
\text { Procedure }\end{array}$ & Precaution \\
\hline $\begin{array}{l}\text { Waste in } \\
\text { general }\end{array}$ & $\begin{array}{l}\text { Dispose of it } \\
\text { after 8:00 PM } \\
\text { using a garbage } \\
\text { volume } \\
\text { disposal bag. }\end{array}$ & $\begin{array}{l}\text { Excludes recycled } \\
\text { or food waste. }\end{array}$ \\
\hline $\begin{array}{l}\text { Food } \\
\text { waste }\end{array}$ & $\begin{array}{l}\text { Dispose of in } \\
\text { the bag a } \\
\text { volume-rate } \\
\text { waste of food } \\
\text { waste }\end{array}$ & $\begin{array}{l}\text { Dry as much } \\
\text { liquid as possible, } \\
\text { and not include } \\
\text { general waste. }\end{array}$ \\
\hline $\begin{array}{l}\text { Recycle } \\
\text { waste }\end{array}$ & $\begin{array}{l}\text { Dispose of in a } \\
\text { mesh bag for } \\
\text { recycling }\end{array}$ & $\begin{array}{l}\text { Do not include } \\
\text { general waste. }\end{array}$ \\
\hline $\begin{array}{l}\text { Bulk } \\
\text { waste }\end{array}$ & $\begin{array}{l}\text { Register the } \\
\text { disposal via the } \\
\text { Internet or visit } \\
\text { a community } \\
\text { center to report } \\
\text { the disposal. }\end{array}$ & $\begin{array}{l}\text { Wait for the } \\
\text { announcement of } \\
\text { the date and } \\
\text { location of } \\
\text { disposal. }\end{array}$ \\
\hline $\begin{array}{l}\text { Used coal } \\
\text { briquettes }\end{array}$ & $\begin{array}{l}\text { Dispose of in } \\
\text { clear plastic } \\
\text { bags }\end{array}$ & Free collection \\
\hline $\begin{array}{l}\text { Non- } \\
\text { combustib } \\
\text { le rubbish }\end{array}$ & $\begin{array}{l}\text { Throw it into a } \\
\text { PP burlap bag }\end{array}$ & $\begin{array}{l}\text { Garbage that is not } \\
\text { suitable for } \\
\text { combustion } \\
\text { among general } \\
\text { waste }\end{array}$ \\
\hline
\end{tabular}

Source: https://www.changwon.go.kr/ (access

January 2020) 
In Changwon City waste segregation is done by separating waste containers for each type.
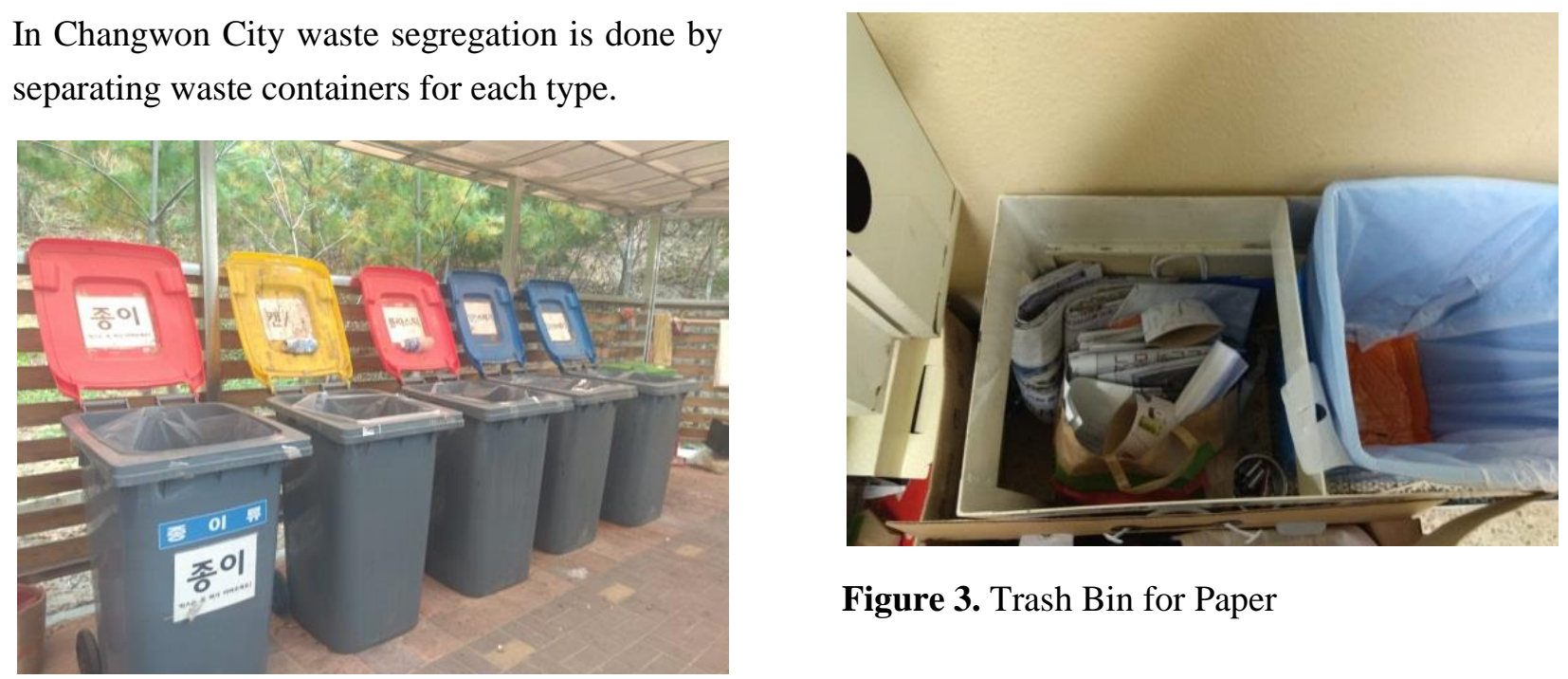

Figure 3. Trash Bin for Paper

Figure 1. Trash Bin for Various Types of Trash
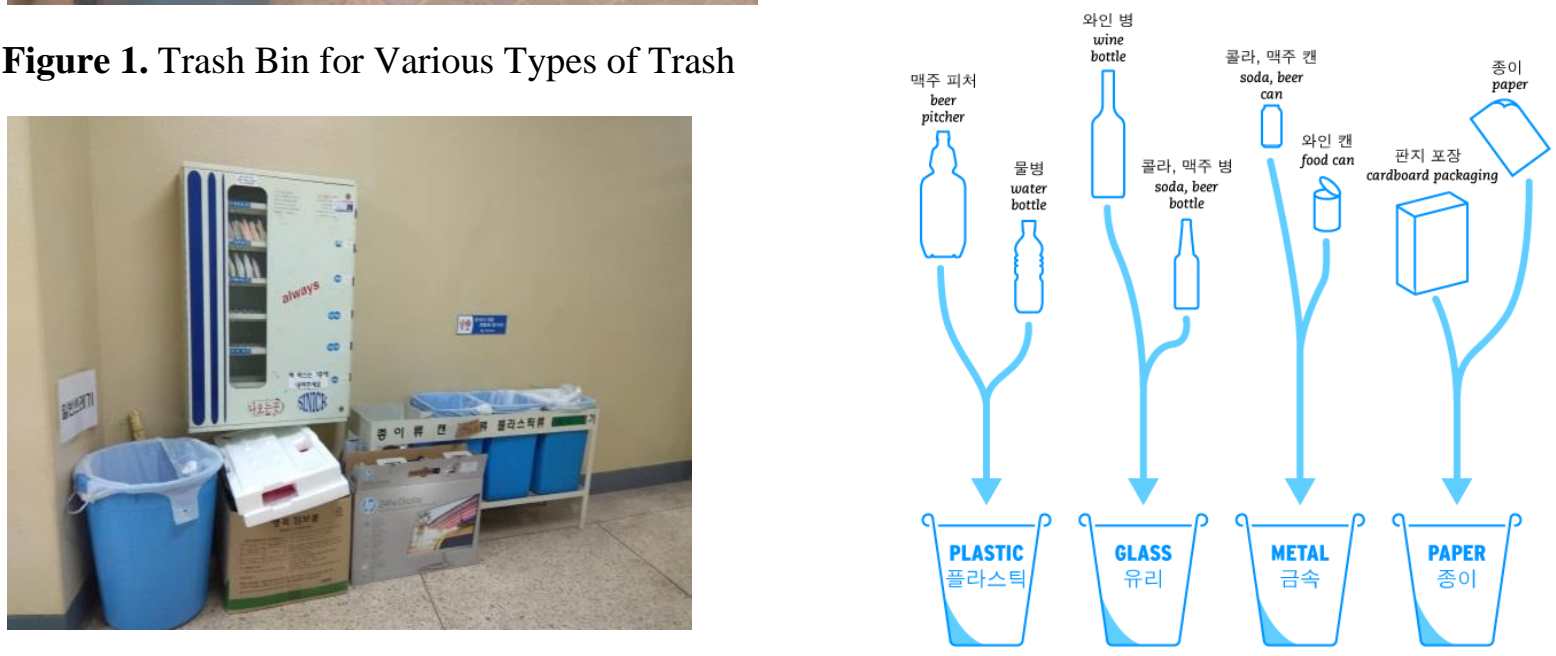

Figure 2. Trash Bin for Waste types of Paper, Glass, Plastic and Food Waste

Figure 4. Classification of Garbage Types

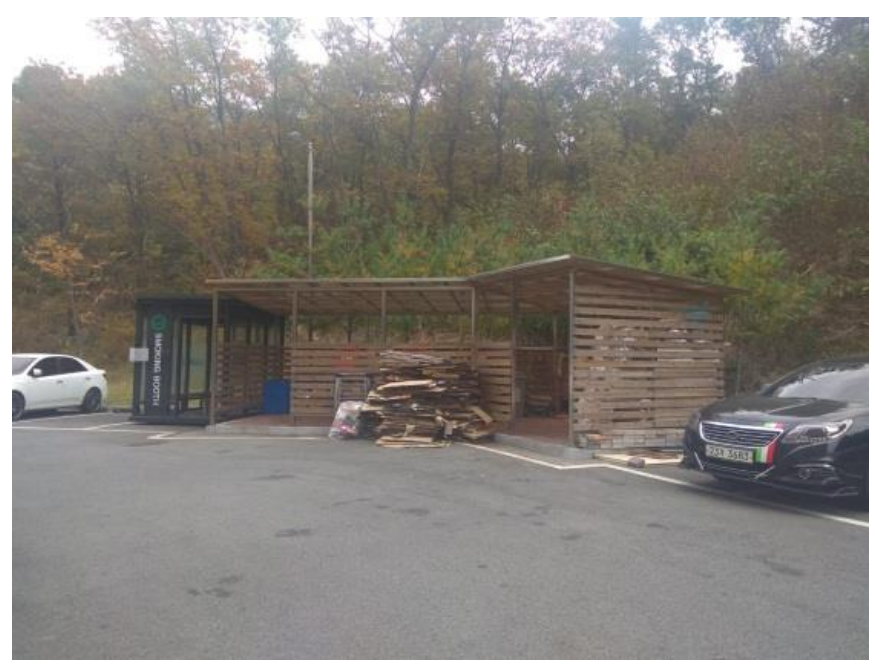

Figure 5. Garbage Collection Site 


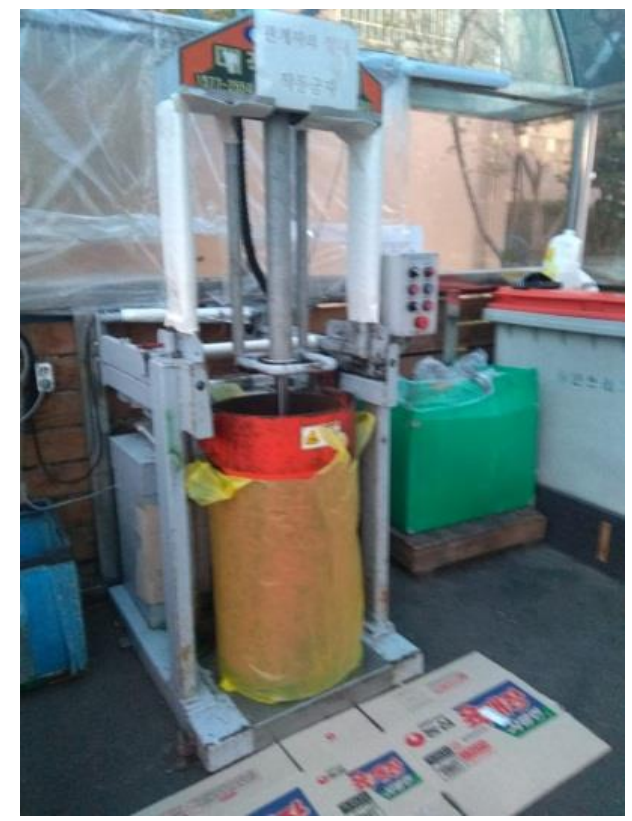

Figure 6. Trash Can Various Types of Trash

Recycling is also carried out by Changwon City, where there are fairly clear procedures. By separating waste for recycling and cleaning, the community must know the schedule and location where to put recycling waste. According to Changwonderful (2012) the recycling collection schedule is divided into two picks. The time of the first recycling waste collection for the Uichang $\mathrm{Gu}$ and Seongsan $\mathrm{Gu}$ areas before $9 \mathrm{am}$. The second collection time for the Masanhoewon Gu, Masanhappo Gu and Jinhae $\mathrm{Gu}$ areas is from 8 to 12 noon.

\section{Conclusion}

Conclusions obtained:

1. Changwon City, South Korea has a good level of participation where South Korea includes policies that must be carried out by the government and society. In addition, people in Changwon City, South Korea are aware of their obligation to participate in managing their waste.

2. The type of management carried out in Changwon City, South Korea, sorting waste before disposing waste by sorting out recyclable waste, food waste, large waste, used coal briquettes and non-combustible waste. In addition, the "Volume-Based Waste Fee" VBWF system has to pay waste according to the volume of waste dumped.

\section{References}

"Changwon Waste and Recycling" (online) https://www.changwonderful.com/changw on-waste-and-recycling/. Accessed 15 February 2020.

"Changwon Garbage Disposal" (online) dari https://www.changwon.go.kr/. Accessed 15 February 2020.

"Germany recycles more than any other country" (online) dari https://www.weforum.org/agenda/2017/12 Igermany-recycles-more-than-any-othercountry/. Accessed 15 February 2020.

Hendra, Y. 2016. "Perbandingan Sistem Pengelolaan Sampah Di Indonesia Dan Korea Selatan: Kajian 5 Aspek Pengelolaan Sampah." Aspirasi, Vol. 7 No. 1 Juni 2016.

Kaza, S. Dkk. 2018. What a waste 2.0 A Global Snapshot of Solid Waste Management to 2050. World Bank group.

Shin Lee. 2016. Volume Based Waste Fee (VBMF) System for Municipal Solid Waste. SMG Policies That Work.

SNI 3242:2008 tentang Pengelolaan Sampah di Permukiman.

Sugiyono. 2018. Metode Penelitian Kuantitatif, Kualitatif, dan R\&D. Bandung: Alfabeta. 
ECOREA 2015 - Environmental Review 2015, Volume 3, Korea. [Available]: www.me.go.kr.

Sang-hun Lee. Policies for Sustainable Resources Management in the Republic of Korea. General Manager, International Policy Research Center Korea Environment \& Resources Corporation. 2005.
South Korea: The Aim Is a Resource-Circulating Society [Internet]. Available: https://global-

recycling.info/archives/3205. Accessed 15 February 2020. 